\title{
Good-Will and Economic-Blockade
}

\section{The Need for a Procedure of Budgetary Control to Make Strong Leadership Consistent with Prevailing Ideals of Justice- \\ An Essential to Efficiency}

\section{By Frederick A. Cleveland}

Professor of United States Citizenship on the Maxwell Foundation, Boston University; Sometime Chairman of President Taft's Commission on Economy and Efficiency which worked out the budget procedure recommended by him for adoption by Congress

T HE problem of democracy is to find the institutional means of reconciling efficiency with popular concepts of justice- efficiency for group achievement with justice in sharing the benefits. Efficiency demands strong executive leadership. Justice demands an institutional means of appeal to group conscience. The demand for reconcilement has given us the most fundamental tenet of the world's prevailing political faith-the principle of popular sovereignty.

The mechanics of democracy have now developed to a point where the chief interest centers in a device adapted to making popular control effective without interfering with efficiency. The principle has long been known and used - that of "economic-blockade"but the institutional means have been at fault. It has been with a view to making this principle effective that budgets and budget procedures have been and are now being devised.

Food for thought may be gathered from Emil Faguet's much read volume, the English translation of which bears the opprobrious title "The Cult of Incompetence"-opprobrious in that it is used as a paraphrase for "democracy."

\section{“The Cult of Incompetence"}

Introducing his essay with Montesquieu's generalization that the controlling spirit of monarchy is honor, of despotism fear and of republics virtue or patriotism, but that each may fail by having too much, Faguet lays down the proposition initially that democracy is rendered incompetent by too much of what the people conceive to be virtue -by reason of conceptions that are essentially democratic but in the nature of things opposed to efficiency.

Starting from these general ideas [those of Montesquieu] I have wondered what principle democrats have adopted for the form of government which they favor [i.e. the principle underlying our constitutions]. And it has not required great effort on my part to arrive at the conclusion that the principle in question is the worship and cultivation, or, briefly, the "Cult" of incompetence or inefficiency. (p. 14.)

Faguet's argument in support of this proposition is that the morality of democracy is unsound, and by reason of this it is incapable of or rather unwilling to permit the development of the institutional agencies that are effective.

Because this assumption is not uncommon nowadays, it is worth while to review the evidence and the argument made use of to convince the reader. A careful perusal of the text discloses that the evidence relied on is a miscellaneous assortment of historic happenings, which he sums up in the sentence: "It is intellectual incompetence and moral incompetence which is sought instinctively in the people's choice." 
If possible it is more than this. The people favor incompetence, not only because it looks on moral competence from the wrong point of view, but because it desires before everything, as indeed is very natural, that its representatives should resemble itself.

So far as logic is relied on in his appeal to reason, his syllogism is this:

First Premise (assumed, not stated): The purpose of political organization being to enable its membership to avail itself of the benefits of coöperationthe competence of a group to achieve its objectives depends on: (1) a sound morality - a morality which will prove effective as a bond of union, and (2) specialization - an arrangement of the personnel through organization suited to the allotment of tasks to persons especially qualified by training and experience.

Second Premise (to establish which the volume was written): The "Cult" of democracy is opposed to both: The morality of democracy is unsound; its bond of union prevents specializationoperates to eliminate the competent from the public service.

Conclusion: Democracy, "The Cult of Incompetence!” Democracy unfit to survive!

The philosophy of democracy is "unsound," he tells us, because "high morality is imputed to those who share the dominant passions of the people"; and in representative government "the people desire . . . that the representatives should resemble itself."

In organizing the public service, the people fail to provide themselves with the institutional means for making cooperation effective because "first and last, democracy . . . wishes to do everything itself." And when "forced by historic events and perhaps by necessity to govern by delegates" then by the same token "the representative government wishes to do everything itself." Democracy excludes compe- tent persons from service and in its institution building refuses to provide for "specialization" not alone because it "imputes high morality to those who share the dominant passions of the people," but

In addition to this sentimental reason, is another, which is extremely important, for it goes to the very root of the democratic idea. What is the people's one desire when once it has been bitten by the democratic tarantula? It is that all men should be equal. . . . Democracy is thus led . . . irresistibly, one may say, to exclude the competent.

This thesis so ably maintained is important not alone by reason of the reception given to Faguet's indictment but because it seems to justify an attitude and practices that have been opposed to the successful working of democratic government from the earliest times-an attitude and practices that are responsible for the very happenings pointed to by democracy's critics to prove its shortcomings.

\section{The Fallacy of Faguet's Reasoning}

Faguet's first fallacy is found in the falseness of the assumption, that it is "unsound" to impute "high morality . . . to those who share the dominant passions of the people." What are these dominant passions? The controlling emotion among all peoples at all times has been what they are pleased to call "justice." These "dominant passions" have had their rise in moral sensibilities. Seer, prophet, poet, artist, in word, color and song, have interpreted them, and found sympathetic response; and the harmonies of feeling thus aroused have been the ties that have held when all else has failed. The strongest bond that associate groups have known is the common impulse to strive for the right and to unite in opposition to that which is thought to be socially wrong. The sentiments 
which we recognize as group conscience and which find expression in common phrase as ideals have proved to be the only sure foundation upon which great coöperative institutions may be built. It is insistence on these ideals and standards for judgment that is characterized as the unsound morality of democracy-insistence on the point that those who are entrusted with the exercise of powers shall be inspirited with a desire to serve and that in service they shall exemplify that high idealism which, impersonated, the people bow down before and worship as their God. This is the morality that Faguet finds it necessary to challenge in order to establish his conclusion.

His second fallacy is found in reliance on a false interpretation of historyhis unsupportable fact-conclusion that democracy is opposed to high "specialization" and that, by reason of adherence to the ideal of equality, competent persons are excluded from public service. The very opposite is true: In response to the impulses and demands of democratic constituencies for service, the amoebic type of institution (the type in which the king was law-giver, judge and executive) has passed out; and in its place democratic governments have grown to be the most complex, the most highly specialized of all political organisms. And the further fact is to be noted that instead of the "cult" as such putting a premium on mediocrity, the greatest leaders of modern time have grown up in the service of democracy. It is true that men of commanding ability have been exiled; but not for the reasons assigned. Demagogues have found their way into public favor, but not because the people prefer demagogues; rather because those who were opposed to democratic ideals in practice have perverted the institutional means designed to protect the people against demagogues.
We come now to Faguet's conclusion that democracy is essentially a "cult of incompetence" and is unfit to survive: Not only has he failed to establish it by reasoning process that such should be the case, but the empirical judgment of history is that the conclusion is false. History tells us that out of the heroic struggles within and between politically organized groups, the very ones whose institutional right to exist is questioned have been the ones that have risen triumphant. The monarchies, the aristocracies, the oligarchies, and all of the political rubrics established on the "isms" of class morality and class privilege have gone down. They have not only been "weighed in the balance and found wanting," but they have been cast off by society while democracy has been embraced.

\section{Essentials of Coöperation}

This brings us to these positive assertions - the preachment of this essay: That the essentials of effective coöperation are: (1) strong executive leadership, and (2) good-will of the coöperating membership; and that democracy as a cult recognizes these as essentials and seeks institutionally to provide for them. From which, if conceded, the conclusion follows that, insofar as there has been incompetence or inefficiency (and we all can find much of it), this has been due to failure to provide an institutional means adapted to the realization of ideals or to the subversion or impairment of the institutional means of achievement already established.

As opposed to the view expressed by Faguet, it is asserted that democracy is a cult upon which may be erected a polity capable of developing the highest efficiency. In this lies the strength of democracy. Recognizing that the purpose of political association is to enable citizens to avail themselves of 
the benefits of coöperation, recognizing that coöperation is made possible only through leadership and good-will, let us stop a moment for reflection. Does democracy provide for both? Is goodwill necessary to strong leadership? And is the morality of democracy such as makes for good-will?

\section{LEADERSHIP AND GoOd-WILL}

Can any other conclusion be drawn than this: That democracy stands out above all others as the cult of goodwill? What is this cult? It can be summed up in four words: "Service," "liberty," "equality," "brotherhood." In the meaning of these four words are wrapped up the ideals that form the basis of the social ethics of democracy. The most fundamental of all is "service." This is the basis of all of the world's highest idealism. In its widest application it is the very soul of patriotism-it is the standard in the weights and measures used by democracy for all its individual and group valuations. Present-day interpretation compels a morality that carries with it the notion that, on the day of judgment and at all times when choice is to be made, service to one's fellows must stand above self. When applied to the whole group, the moral concept "service" is expressed in terms of "brotherhood."

"Service" speaks in terms of duty. In order that this concept may have an appeal binding on the conscience, however, there must be a class vision of corresponding rights. A common consciousness of right which we call "justice," therefore, asserts that the politically organized community shall be "free,"--this freedom being conditioned only by the concept of "equality." Under conditions of inequality, enforced through institutional restraint, "liberty" was first given a negative meaning. But with slavery abolished, the concept of liberty is interpreted as "the right of self-determination," and thus is given an unselfish significance. By "the right of self-determination" is meant the right of the individual to choose what service he shall undertake to render to the group - the right of each member to choose his own career and make the most of it so long as he chooses to do something that is serviceable. Thus the only restriction to be placed on the individual is the broader right of society-a concession to goodwill-the right of the group to decide what is serviceable and what is not. The only restriction imposed on the individual is that he shall gain his liberty through the service gate: that he shall gain his freedom, economic and spiritual, by service to others.

Thus, adopting this view of liberty, only those who are not social-minded are not free. Democracy sets up no barriers to self-determination except against those who claim for themselves privileges which are not accorded to others, or who assume that their own judgment of right, warped as it must be by self-interest, is superior to the group conscience. As against this holier-than-thou attitude, democracy weaves into its moral fabric its ideal of equality-that each shall have an equal right of self-expression, an equal right to appeal to the group conscience, and an equal opportunity to achieve success in whatever specialized field of service to his fellows he may choose.

\section{Ideals of Democracy}

It is clear also that this fundamental morality in the interest of establishing and maintaining good-will carries to all the institutional organs and agencies of democracy - to its leaderships and its followings, to the individual members and to "the people" as a political aggregate. Making practical application of this concept of social justice to every- 
day affairs, democracy insists that the associate group "the people," shall have the right by well-considered majority opinion to decide not only what is serviceable and what is not, but also what services shall be left to individual initiative-and also what services shall be rendered by its common agency, the government. Having decided that certain services can best be rendered by its common service organ, the government, it insists that society served shall determine what shall be performed by national, state and local agencies, and how each shall be organized.

And with respect to that broad domain left to private initiative, it insists that it is for society to decide what may be performed by corporate and what by non-corporate agencieswhether eleemosynary or those engaged in profit-taking; what shall be regulated as public utilities; what shall be left to private competition made effective through bargaining; what services left to private bargaining shall have professional and technical qualifications prescribed to insure efficiency; what shall be regulated in order to protect health and provide for safety; what provision shall be made to prevent profiteering through capitalistic monopoly and control; what shall be the content and qualifications given to individual property rights and trusteeship.

In fact, every institution and agency of coöperation, whether private or public, must come within the rule of serviceability - all private arrangements, and all the agencies developed must gain their status and come under the rule of democratic justice; a rule of justice which, being established by the people, leaves no social reason for illwill-provided it leaves to each individual the institutional means of appeal to the consciousness of right and wrong in the community. Therefore, whatever is the judgment of the group fairly arrived at, there is no cause for ill-will.

\section{Organization for Efficiency}

Further observation is to be made that democracy in its institutions has adopted the only polity that provides for establishing and maintaining goodwill. This is the meaning of the "folkmote" and the representative system. Adopting the principle of popular sovereignty as a means of giving expression to the right of "the people" to rule, it has been necessary to develop in the body politic organs of volition as well as organs of action; and democracy has developed specialized organs of popular perception, resolution and control as distinguished from those for service. To this end democracy has recognized the fact that an associate group can not think, can not find out what its feelings are, can not have a common opinion or a common will without leadership; and so democracy has developed in its institutions:

(1) Organs for leadership in deliberation, criticism and discussion-reaching out for group consciousness of right or justice.

(2) Organs for leadership and discipline in coöperate action-reaching out for achieving objectives through team-work.

As in the human body, the organs for deliberation must be independent of the organs of motorization-both being subservient to the will. And as a means of making popular sovereignty - the will of the people - effective without detracting from the strength of leadership or interfering with the discipline and teamwork relied on for efficiency in action, democracy has undertaken to inhibit all interference with the doers on the part of the determiners except to approve or dis- 
approve of the objectives with respect to which power is to be developed and used. Thus the deliberative and the executive branches are made independent of each other. To the executive is given all powers of action; to the deliberative branch control over supplies and to put into the hands of the determiners control over supplies-control over the purse. It has been the confusion of these two functions that has led to incompetence. ${ }^{1}$

\section{Economic Control}

It is quite apparent that the representative, deliberative, determining organ of conscience in the body politic could not control those to whom have been entrusted the direction and use of its organized and disciplined forces (military and civil) in any other manner than that of "economic-blockade" without upsetting the whole institutional arrangement and destroying

\footnotetext{
${ }^{1}$ In support of the allegation that this "cult" of democracy has driven the most competent as leaders out of public service, Faguet tells us that men of commanding ability have no alternative other than to engage their talents in private business. What do we find in the services thus provided for by society to make them attractive to leaders who are not attracted to service in the government? What do we find in the conception and morality of these private undertakings that makes them different? We find that all the sizable private undertakings are membership bodies-partnerships or corporations; that corporations in organic acts provide for "specialization" while partnerships are "non-specialized" brotherhoods; that in corporations which are held up as having reached a high mark of efficiency, the leaders are chosen by the members; that in form these corporations provide the same organs for membership control and for action as do those established by the people for common service without profit. Their differences lie: (1) in the qualifications for membership-membership which in private corporations is limited to a dollar aristocracy; and ( $(2)$ in the selfish inducement held out to the "members" and managers by way of "profits," giving them a right to speculate in the services of others thus drawing a line in right and opportunity, between "capital" and "labor." By giving control to those
}

the good-will of the members. The effectiveness of this form of "moral suasion" finds illustration in the World War. This was the weapon which the Allies sought to use against the organized Central Powers. But in order to make its "economic-blockade" successful, it was necessary to control all of the shipping of the world-the international carriers of supplies.

The device resorted to as a means of accomplishing this end without taking over the ships themselves or interfering with the discipline of a single one of the ships' crews was to set up a representative "allied council," that sat at London, to control "the bunker privilege." This council was given control over all of the coal-bunkers and other stations where ocean-going vessels could get supplies. Then this "council" issued an order to the effect that before any master would be given the privilege to coal and take on other needed supplies he must give satisfactory account of his last trip and explain his plan and purpose for the next one. If he could do this in such

associates commonly called "capitalists" and permitting their "manager" to buy the services rendered to society by "labor" at the lowest possible cost, then to sell the product at the highest price obtainable - there is a constant inducement to exploit both, the laborer and the public. The result has not been whole-souled coöperation, but "strife." At best coöperation has been only half-hearted, for the first fruit of this kind of traffic has been loss of the good-will.

And how has this loss of the good-will of the workers, and not infrequently of the public, affected the success of those large privately conducted services? Have they been outstanding successes? Some of them have succeeded in gaining large profits for their leaders and for the dollar aristocracy that was given the standing of "members." But in the long run most of them have gone the way of the political oligarchies and aristocracies that left out of account the need for the continuing good-will of the whole coöperating group.

Not only has their record been one of high institutional mortality, but we find that, however 
a manner as to retain the good-will of the "council," well and good. He would have appropriated to him, and was "privileged" to draw, the necessary supplies. But if he could not, if he failed to obtain or retain the goodwill of the "council" he had nothing to do but resign or tie up the ship. For lack of supplies the company could not move the ship until a captain was put in charge, in whom the "council" had confidence.

\section{Procedure of Enforcement of "Economic-Blockade"}

The instrument designed for making control over "economic-blockade" effective in the hands of the representative appropriating branch of modern democratic governments is known as a budget. And the procedure used is what has come to be known as budget procedure. The essentials of a budget procedure adapted to making control over executive leadership and action effective are:

(1) That the executive (the one who

able one or another leader may have been, the cost and waste of this type of autocratic organization in business has been far greater than the cost and waste of all the wars for democracy, plus the entire costs (not to say waste) of both military and civil establishment. Instead of working for the conservation of material and human resources, the losses to "capital" alone have been little short of the most wasteful of all political undertakings. For example, the losses to "capital" due to business "reverses" in the period immediately following the Civil War were greater than the cost of the war. Consider also that most of the military struggles have been provoked by this feudal rivalry. Consider also that the loss and waste to the "non-members," (the workers) has far exceeded the losses to the dollar aristocracy.

It may be urged that the losses to "capital" were not a social loss, because the bankruptcies and reorganizations did not destroy natural resources, plants and tools. But the loss to the workers from shut-downs, dislocations and the other upsetting circumstances of business feuds and misadventures resulting in unemployment is to be held accountable for execution of the plan, the one whose action is to be controlled) must be the one to prepare, explain and defend the budget to the members of the appropriating body.

(2) That this explanation and the inquiry, criticism and discussion relating to it, shall be in sight and hearing of all those who are to vote on the question of supplies.

(3) That the appropriating body shall withhold support until a majority of the membership and the executive can reach an agreement as to what course shall be taken.

(4) That in case an agreement can not be reached between the executive leader and a majority of the appropriating body, provision must be made for appeal to the people on the questions or issues involved.

The first three of these requirements are essential to the effectiveness of any form of "economic-blockade"the intelligent use of control over the purse by a body or council independent

has been a social loss. The loss in working force due to lack of good-will, the cost of the human turnover, inanition, disloyalty, opposition to discipline and sabotage in industries managed on a basis which has ignored good-will, can not be estimated. And what have been the social results of this kind of organization and leadership? Sixty-five per cent of all the wealth is in the hands of two per cent of the people. Only thirtythree per cent of the people have a ratable share and these are largely farmers. Sixty-five million people in this the most productive of all countries are within a few days of the bread-lines.

These are the results that give color to appeal for justice which upset the morale of industry, and cause men to lose faith not alone in "capital" but in the private institutions as well. There is nothing in the public institutions commented on favorably by Faguet and others, to carry conviction that they are to be patterned after in our out-reaching for efficiency. And the more forward-looking industrial managers are coming to recognize the need for adopting, in the interest of industrial coopperation, the morality, the ideals and even the methods of democratic control as a means of conserving good-will. 
of the executive; the fourth requisite is necessary to a democracy, because it is only through the operation of such a principle that the controlling process can reach to and secure the good-will of the people. Anything short of this must result in the domination of the government by an irresponsible oligarchy. The loss of good-will that has obtained in democratic states, the official incompetence and the inefficiency that have crept into their governments have been due to failure to adhere to these principles of constitution-making, failure to provide for procedures necessary to making economic control over executive leadership effective.

\section{Objective: Good-Will}

In France, instead of making the prime minister responsible for preparing, explaining and defending the service program which he is called upon to administer and for which supplies are asked, this is taken over by a "budget commission" made up of members of the appropriating body who had been selected by lot. The effect of this has been to shift responsibility for leadership and to confuse the functions of review, criticism and deliberation on moral questions with those of action; it impairs discipline and interferes with efficiency, causing "budget-making" to be a matter of patronage; furthermore, it operates to deprive the people and their representatives of the knowledge necessary to the intelligent exercise of popular control.

In England under Gladstone, a method was worked out suited to the effective dramatization of the work and program of the government for which support was asked (a procedure adapted to conserving the good-will of the nation); but "party" organization and, since 1914, the "coalition" has rendered this procedure ineffective. In Canada, the critical faculties of the dominion parliament and the critical faculties of the several provincial parliaments have been taken over and subordinated to the executive whose action and proposals are to be brought under review.

In the United States, executive leadership has been made subservient to "standing committees" which in turn have been controlled by "leaders" who have no place or responsibility in either branch of the government. The controlling body itself in order to protect its own "invisible" and "irresponsible" leaderships, has refused the executive the right to come before it while sitting as a reviewing and appropriating body. All the service plans and expenditures have been secret arrangements. And now under the guise and name of a "budget procedure," it is proposed, and it seems probable that measures will be passed by the next congress, to give legal sanction and increased power to the chairman of these "standing committees" by constituting them a "super-committee," an arrangement which can have no other effect than to make "invisible" and "irresponsible" leadership in the government more powerful and offensive to the people than ever before. So long as this system prevails, the voice of the electorate can be no more effective or constructive than a voice of protest; the prevailing spirit of the people must be that of ill-will.

\section{Conclusion}

The principle of "economic-blockade" is not an invention of democracy. It has been the institutional method of control-without-violence from the beginning of time. It has been the principle through which paternalism (both benevolent and malevolent) has operated and is still operating to maintain its leadership. It has been to establish an economic-blockade, which 
would prove effective for the ends and purposes of the dominant leadership, that wars and industrial strife have been carried on. The contribution of democracy to the world's progress has been to provide the machinery whereby leadership may be made subservient to prevailing concepts of justice; and, in the institutional outreachings of democracy through its experiences to achieve this purpose, it has asserted and sought to gain the right of economic-blockade. Therefore, the instrumentalities through which society has insisted that this right shall be exercised have been its institutions for justice; its institutions for the arbitration of controversies between persons and groups with the conscience of the nation as arbiter; its courts and its representative assemblies to which have been given the right to control the wealth and resources of the whole political society and its members.

But to make these establishments effective for justice it has been found necessary: (1) to bring the leaders (the ones whose acts or proposals are made the subject of review) before the court in order that they may be confronted by their critics and accusers; (2) to provide for a fair trial based on evidence and not on gossip or rumor or ex-parte statements and appeals; (3) to have these proceedings conducted in the open so that the whole associate membership can "listen in." "Star Chamber" trials, or decisions reached by "diplomacy" or other secret methods, can have but one purpose: to use the machinery of "economic-blockade" for selfish, non-social ends-a perversion of the institution set up in the name of justice in the interest of "patronage" and "spoils."

The political and social unrest of today, the want of confidence in leadership, the waste and inefficiency in both public and private service, the questioning of ideals and institutionsall these are the results of methods employed to defeat the ends and purposes of democracy. Out of "secret diplomacy" and "closed-door" methods of deciding questions of public policy by negotiation and agreement between members of "committees" who assume that they are more competent to decide what is best than are the members of a representative body commissioned by "the people" after full hearing and fair trial-out of these methods comes ill-will; for when associate groups lose confidence in their leaders, no international means is provided for the transfer of power to others whom they trust and there is only one thing that can be expected, viz., that everything possible will be done to undermine the authority of those who are in power. All this makes for inefficiency and waste - the waste of loss of discipline, loss of sabotage, revolution-which could be obviated by providing the conditions favorable to effective coöperation. Unless and until methods of control are provided whereby those who are distrusted may be forced to retire in favor of leaders who are trusted, the people will not consent to any arrangement which makes for increased competence, and political action can not have a constructive objective.

Conversely, when provision is made for executive leadership in planning as well as in the execution of plans by those who are trusted, there are no powers which people will withholdconstitution or no constitution, law or nolaw. With the objective to be gained clearly in mind and approved, with the good-will of the whole membership of the associate group back of its leadership for achievement, every institutional and physical obstacle will be set aside in the interest of efficiency.

These are the considerations which 
society must weigh in the exercise of choice between institutional alternatives for control over executive leadership, via "economic-blockade"whether applied to programs of national welfare or international alliance and defense: Are the methods and procedures proposed, or in use, adapted to the maintenance of the Sovereignty of Good-Will? Are they adapted at once to the development of the strongest, most able leadership for achievement that can be found, which can be trusted -leadership which in the interest of efficiency is endowed with all power except that of control over supplies? The further development of the mechanisms of democracy must be with a view to the utilization of strong executive leadership, at all times, making it consistent with the maintenance of good-will by a procedure of economic control, the effect of which will be to enable the people to transfer the scepter of power from one strong leader to another without loss of institutional momentum or impairment of efficiency.

\title{
Budget Making in Philadelphia-Its New Provisions and Operation
}

\author{
By Wright Hoffman \\ Instructor in Economics, University of Pennsylvania
}

$\mathrm{O}^{\mathrm{s}}$ N June 25, 1919 a new charter for the city of Philadelphia was approved by the State Legislature. Among the provisions included were important changes in budgetary procedure. Prior to that time both the preparation and the final enactment of the budget were in practice, carried out by Councils, and as such would commonly be classified as a legislative budget. Under the provisions of the new charter, the powers of the Mayor have been enlarged and, in its preparation, at least, the financial program, as now provided for, is an executive budget. Though sufficient time has not elapsed for a thorough test, a comparison of the practice thus far with the provisions may prove of interest.

First with regard to the requirements of the law. On or before October fifteenth of each year the Mayor is required to prepare and submit to Council the budget for the following year. This estimate must contain:-
1. A statement of estimated receipts for the following year, including money that it is proposed to borrow.

2. A statement of liabilities of every kind for the ensuing year designating which are to be met from current receipts and which from loan funds.

3. A statement of estimated expenditures for the following year of "all departments, officers, boards, commissions, trusts, committees, or other agencies" whose financial requirements are to be met from either current receipts or loan funds over which Council has control.

4. A statement of the borrowing capacity of the city.

The first, second and fourth statements above are furnished to the Mayor by the City Controller. The statement of estimated expenditures must be made up by the Mayor from the estimates supplied him by the various departments, boards, etc., and can be revised by the Mayor as he sees fit. It is further provided that the form of the Mayor's estimate as submitted to Council shall be as Council may determine. 